\title{
Structure, physiognomy and floristic composition of a Schinopsis balansae (Anacardiaceae) forest in the Southern Chaco, Argentina
}

Juan Pablo Lewis, Eduardo F. Pire and Ignacio M. Barberis

Facultad de Ciencias Agrarias, Universidad Nacional de Rosario, Casilla de Correo 14, 2123 Zavalla, Argentina. Fax 05441-257164.e-mail: lewis@cidoc.edu.ar

\section{Recibido 26-IX-1996 Corregido 5-II-1997 Aceptado 7--IV-1997}

\begin{abstract}
Amazonia and the Gran Chaco are the largest phytogeographic units of tropical and subtropical South America. The Santa Fe Forest Wedge is the southernmost portion of the Eastern Chaco, where the Schinopsis balansae forest (Quebrachal) is the most widespread and characteristic community. A detailed analysis of the floristic composition, physiognomy and vegetation structure was carried out in $3210 \times 10 \mathrm{~m}$ contiguous plots sampled along two transects in one of these forests near Vera, Province of Santa Fe, Argentina. All woody individuals higher than $0.6 \mathrm{~m}$ present in the plots were recorded, identified and their height and crown diameter measured. With these data, cartographic diagrams and vegetation profiles were drawn. Woody species were classified according to leaf size, leaf texture, presence of spines and phenology. This quebrachal is an open forest with very complex structure and heterogeneous floristic composition. Most woody species of this forest are deciduous, with small leaves and frequently with spiny structures. It has two higher tree layers of $S$. balansae and Acacia praecox, and a lower tree layer of Achatocarpus praecox with younger individuals of the higher strata species and some large shrubs. There is as well a $2 \mathrm{~m}$ high shrub layer. The tree canopy is discontinuous, with gaps that can be rather large, where the soil is covered by a dense grass layer. This forest is much like other $S$. balansae forests of the Santa Fe Forest Wedge, but quite different from most other forest areas of the Gran Chaco.
\end{abstract}

Key words: Argentina, Chaco, floristic composition, forests, physiognomy, stratification, vegetation structure.

The Chaco $\left(15^{\circ}\right.$ to $\left.35^{\circ} \mathrm{S}\right)$ is a very large alluvial plain that covers about $1000000 \mathrm{~km}^{2}$ of Eastern Bolivia, Western Paraguay, Northern Argentina and a very small part of Southern Brasil. The Paraguay and the Paraná rivers run along the east boundary and pre-Andean mountains on the west. Climate is seasonal tropical-subtropical, mean annual temperature varies from $18^{\circ} \mathrm{C}$ in the $\mathrm{S}$ to $26^{\circ} \mathrm{C}$ in the $\mathrm{N}$ with an absolute maximum of $48^{\circ} \mathrm{C}$ and there are frosts in winter. Rainfalls occur mainly during summer (from September to April) and then, there is a strong winter drought of variable length. Annual precipitation ranges from $1300 \mathrm{~mm}$ in the east to less than 500 $\mathrm{mm}$ in the west, though it increases when approaching the mountains (Burgos 1970, Spichiger and Ramella 1989).

The Eastern Chaco is wet and the Western Chaco is rather dry (Ragonese and Castiglioni 1970, Cabrera and Willink 1980, Ramella and Spichiger 1989, Spichiger et al. 1991). The Pilcomayo river separates the Northern Chaco from the Austral Chaco that Cabrera (1971) divides in four districts, the Eastern characterized by the presence of Schinopsis balansae Engl. the Western by Schinopsis quebracho-colorado (Schlecht.) Barkley et Meyer, the Serrano district by Schinopsis haenkeana Engl. and the Savanna district which is in the Submeridional Lowlands (Gollan and Lachaga 1939) and is characterized by the Spartina argentinensis Parodi grasslands and the almost absence of trees (Lewis et al. 1990). The southernmost segment of the Eastern Chaco is the Santa Fe Forest Wedge ("Cuña boscosa"), placed between the Submeridional Lowlands and the Paraná river from parallel $28^{\circ} 00^{\prime} \mathrm{S}$ to $30^{\circ} 30^{\prime} \mathrm{S}$.

The Santa Fe Forest Wedge vegetation is a mosaic of forests, savanna grasslands and hygrophylous communities ordered along moisture and salinity gradients correlated with topographic elevation (Lewis and Pire 1981). The S. balansae forests ("Quebrachales") are on halo-hydromorphic soils (Espino et al. 1983, 
Mussetti and Alconchel 1986), in the middle of the elevation gradient between Prosopis nigra (Gris.) Hier. var. ragonesei Burk. forests ("Algarrobales") and the mixed dense forests ("Bosques chaqueños") (Lewis and Pire 1981). The Quebrachales were heavily lumbered in the first half of this century for tannin and later on, until present times, for fuel extraction and charcoal production.

Plant communities can be floristically or physiognomically analysed. An association is a community with defined floristic composition and a formation is defined on the physiognomy and structure of the component plants (MuellerDombois and Ellenberg 1974). Key structural properties include the height of trees, whether they tend to have their crowns in layers or not, their spatial distribution and canopy architecture and the presence of different kinds of climbers and epiphytes. Physiognomic properties include whether or not the forest is evergreen, tree crown shape, morphology of the leaves (size, shape, thickness, margin), presence of spines, etc. (Whitmore 1990).

The floristic composition, horizontal and vertical structure and the physiognomy of several communities of different areas of the Chaco have been analysed at different scales by Ragonese and Covas (1940), Ragonese and Castiglioni (1970), Sarmiento (1972), Sejzer (1973), Lewis and Pire (1981), Gräffe et al. (1991), Lewis (1991), Spichiger et al. (1991), Prado (1993a,b), as well as many other authors. However there is not a detailed analysis at a fine scale of a $S$. balansae forest ("Quebrachal") of the Santa Fe Forest Wedge with special reference to its horizontal and vertical structure, physiognomy and floristic composition. Therefore, the object of this paper is to analyse these aspects in a stand of Quebrachal near Vera (Santa $\mathrm{Fe}$, Argentina), previous to a long term study of its dynamics.

\section{MATERIAL AND METHODS}

The study area: It is located in the experimental center of the Provincial Ministry of Agriculture at Las Gamas, near Vera $\left(29^{\circ} 28^{\prime} \mathrm{S}-60^{\circ} 12^{\prime} \mathrm{W}\right)$, Province of Santa Fe. Although this stand is not completely mature, not even in a steady state, it is partially recovered and cattle grazing, mild wood extraction and sporadic fires are the main disturbances.

Data collection and analysis: On March 1989, 22 contiguous 10 x 10 m plots were sampled along a transect and another ten plots of the same size were sampled along a second discontinuous transect parallel to the first one. All individuals were counted and mapped on a grid of quadrats, their crown diameters were measured and the height of some individuals was measured with a clinometer. With these data cartographic diagrams and vegetation profiles (Davis and Richards 1933, Richards 1952) were drawn (Fig 2 and 3). The general cover of woody species of each plot was measured from the cartographic diagrams with a leaf-area meter. Woody species were classified in five classes according to their growth form and maximum height: 1) trees taller than $10 \mathrm{~m}$. 2) trees from 8 to $10 \mathrm{~m} .3$ ) trees smaller than 8 m. 4) shrubs taller than $2 \mathrm{~m}$. and 5) shrubs smaller than $2 \mathrm{~m}$ high. Voucher specimens were collected and deposited in the University of Rosario Herbarium (UNR).

Leaf size of all woody species present in the stand was determined measuring 20 leaves (leaflets in the case of compound leaves) taken randomly from one mature individual. Leaf sizes were grouped into Raunkiaer (1934) leaf size classes (microphyllous $=2.25-20.25 \mathrm{~cm}^{2}$, nanophyllous $=2.25-0.25 \mathrm{~cm}^{2}$, leptophyllous $=$ less than $0.25 \mathrm{~cm}^{2}$ ). Leaves were classified as well in four texture classes: filmy, membranous, co aceous or succulent (Dansereau 1957). Species were considered evergreen when mature individuals have green leaves the whole year around. Different degrees of deciduousness were not distinguished. The presence of spines, including any thorny structure either on foliage, branches or trunk was recorded (Sarmiento 1972).

\section{RESULTS}

Eighteen tree and 14 shrub species were found in the stand. However, some were so rare that they were not recorded in the sampled plots (Caesalpinia paraguariensis (D. Parodi) Burk. Jodina rhombifolia Hook. et Arn. Patagonula americana L. Ruprechtia laxiflora Meissner and Banara umbraticola Arechav.). Although some species, like $S$. balansae, lose their leaves only 
for a short period, most species are deciduous, with small leaves and often with spiny structures. There were neither tree species with succulent leaves, nor shrub species with coriaceous leaves. There was only one shrub species (Senna pendula var. paludicola (Willd.) Irwin et Barneby) with compound leaves (Table 1). Of all individuals recorded $(\mathrm{N}=459) 84.7 \%$ were deciduous, with single $(61.7 \%)$, microphyllous (54.9\%) membranous leaves $(52.3 \%)$, and with spiny structures $(79.3 \%)$ (Table 2). Similar results were obtained when crown cover was analysed (Table 2).

Acacia praecox Gris. and $S$. balansae were the most abundant tree species, and Celtis pallida Torrey the most abundant shrub. These two tree species also have the highest cover, while the cover of most other species is minimal. Shrub cover (9\%) is not very high, unless Achatocarpus praecox Gris. (10\% cover), which is considered a small tree in this paper, were considered a shrub. Acacia praecox is also one of the relatively most frequent tree species, but some other species with a comparatively high relative frequency, like Geoffroea decorticans (Hook. et Arn.) Burk. cover very little ground surface (Table 1).

The $S$. balansae forests are open forests, with open spaces. The general cover of woody species is $63 \%$ and there is a $35 \%$ overlap in cover of woody individuals. Plot cover is not uniform, as there are some places with a dense canopy, like in plots $8,11,12,13$ and 26 where woody species cover is $90 \%$ or more, and others with low cover like in plots 3 and 25, where the general cover of woody species is less than $20 \%$, or less than $4 \%$ in plot 24 (Fig. 1). Some plots, like 16 and 21 , have no trees rooted inside the plots, but they have a relative high tree cover, which is the result of tree crowns of neighbouring areas.

Individuals of woody species are clumped. Therefore tree canopy is very dense at some places, but discontinuous, so all along the transects there are gaps of different sizes (Fig. 2). In large gaps there is a dense understory of grasses, while the more shadowy parts of the forest are invaded by spiny bromeliads (Aechmea distichantha Lemaire and Bromelia serra Gris.).

There are two upper ree strata, which are not always easy to segregate from each other. The stratum higher than $10 \mathrm{~m}$ has $S$. balansae as the dominant species, acompanied by Sideroxylon obtusifolium (Roem. et Schult.) Pennington and Aspidosperma quebrachoblanco Schlecht. The other stratum about $9 \mathrm{~m}$ high has Acacia praecox as the dominant species, acompanied by Prosopis sp. (P. alba Gris. P. nigra (Gris.) Hieron. and their hybrids) and other species including young individuals of the highest stratum species. Both strata do not form a continuous canopy, and leave gaps that sometimes can be rather large. Below the upper tree strata there is a layer of Achatocarpus praecox and C. pallida and young individuals of all of the higher tree layers. Below them, there is a very discontinuous and grouped shrub layer, about $2 \mathrm{~m}$ high, forming thickets where it is present (Fig. 3).

\section{DISCUSSION}

The general cover of woody vegetation is not $100 \%$ and the degree of overlapping is not very high, meaning that in some places one or more tree strata are absent. The two higher tree strata do not always overlap, in fact, as shown in Fig. 3, in many places they are segregated from each other, but when they overlap their limits are diffuse. The shrub layer is discontinuous, forming very dense clumps in certain places, while it is absent in many others.

As a result of the uneven distribution of strata and individuals, the structure of this forest is very complex. The complex structure, the clumped distribution of individuals and the uneven distribution of species hypothetically is the result of environmental heterogeneity. Though dynamics and successional processes may also change the structural characteristics of this forest. Soil suface is very irregular, so there are places that often flood while others are well drained (pers. obs.). Most woody species grow on the drier soils, while $G$. decorticans and sometimes Prosopis sp. grow on more wet soils. on flooded soils there is only herbaceous vegetation, mostly grasses and sedges (pers. obs.). As a result of edaphic heterogeneity, the clumped distribution of trees together with their different leaf architecture, probably creates a heterogeneous light environment, so there would be many kinds of biotopes. 
Nevertheless, the environmental heterogeneity of this forest is in need of further research.

Although all woody species of this forest have small leaves or leaflets, the larger tree species as well as the smaller ones have relatively wide leaves, while the intermediate, like Acacia praecox and Prosopis sp. are leptophyllous (bipinnate leaves with tiny leaflets). Shrubs of this forest almost always have relatively large leaves. The leaf size spectrum of this forest is similar to that shown by Sarmiento (1972) who found that $32 \%, 56 \%$ and $12 \%$ of the eastern Chaco woody species were mesophyllous, microphyllous and nanophyllous plus leptophyllous, respectively. It must be borne in mind that the Forest Wedge is the southernmost portion of the eastern Chaco, thus, as a possible consequence of the temperature gradient Sarmiento's (1972) data have more species and also more species with larger leaf sizes. Moreover, at the south of the Forest Wedge is the Peristeppic Thornforest where prickly Mimosoideae (leptophyllous) are dominant (Lewis and Collantes 1973). When leaf size is weighted by abundance or crown cover, the percentage of leptophyllous trees increases in the southern Chaco. Therefore, in the Eastern Chaco towards the south decrease the number of species, as well as individuals, with large leaves. Leaf size spectra of the humid Chaco given by Sejzer (1973) and Eskuche (1986) also show a larger average size of leaves than in the Forest Wedge, while the dry Chaco has a smaller average size of leaves (Sejzer 1973).

Although $61 \%$ of all tree species have spines, almost $90 \%$ of the trees are spiny. in the case of shrubs only about $36 \%$ of the species are spiny, but $56 \%$ of the individuals have spines. Generally, spines are woody structures, but $A$. quebracho-blanco and $J$. rhombifolia have non-woody spines on the tips of leaves. S. balansae has thorns only during the juvenile stage.

This forest is similar to other $S$. balansae forests of the Santa Fe Forest Wedge (Lewis and Pire 1981). In other $S$. balansae forests Ragonese and Covas (1940) did not record some species observed in this forest (Zizyphus mistol Gris. Grabowskia duplicata Arnott, Acacia caven (Mol.) Mol. Lycium cuneatum Dammer, Celtis iguanea (Jacquin) Sargent, J. rhombifolia and Sapium haematospermum Müll. Arg.) but they recorded several others, such as Scutia buxifolia Reisseck, Eugenia uniflora L. Prosopis vinalillo Stuck. Schaefferia sp. Capparis tweediana Eichler, Allophyllus edulis (St. Hil.) Radlk. and Berberis ruscifolia Lamarck, which were not observed in this forest. They also recorded $C$. paraguariensis, $P$. americana, $R$. laxiflora and $B$. umbraticola which were observed but not recorded in the plots in this forest because they were very rare. However, they recorded most of these species farther north, reflecting that species richness increases northwards (Lewis 1991). Ragonese and Covas (1940) did not differentiate the Quebrachal from mixed dense forests as we do (Lewis and Pire 1981, Lewis et al. 1994).

The Quebrachal of the Santa Fe Forest Wedge differs from the Quebrachal of the Argentinian western Chaco where the dominant species are $S$. quebracho-colorado and $A$. quebracho-blanco (Adámoli et al. 1972, Adámoli et al. 1990, Sennhauser 1991). In the dry Paraguayan Chaco, Spichiger and Ramella (1989) and Ramella and Spichiger (1989) also mention a "Quebrachal" with some of the same species (A. quebracho-blanco, Capparis retusa Gris. Z. mistol), but $S$. quebracho-colorado and $A$. quebracho-blanco are the dominants and $S$. balansae is absent. In the humid Paraguayan Chaco Spichiger et al. (1991) mention a xeromesophytic forest of $S$. balansae and Astronium balansae Engl. but they also did not differentiate the $S$. balansae "Quebrachal" from the mixed dense forest (Lewis et al. 1994).

According to Prado (1993b) in the eastern Chaco there are four different kinds of true chaquenian forests, ( $S$. balansae "Quebrachal", Prosopis sp. "Algarrobal", palm forests of Copernicia alba Morong, and Stetsonia coryne (Salm. Dyck) Br. et Rose "Cardonal") and an Austro-Brazilian Transitional Forest with species of chaquenian and amazonian lineage. The two major woody communities of the eastern Chaco have been repeatedly mistaken for a single one (Prado 1993a), the Quebrachal of $S$. balansae and the Austro-Brasilian Transitional Forest or mixed dense forests (Lewis and Pire 1981, Prado 1991, Lewis et al. 1994), although Morello and Adámoli (1974) reported differences between them. The $S$. balansae forest is characteristic of the Santa $\mathrm{Fe}$ Forest Wedge and is probably mainly confined to this area. The ecological optimum for $S$. 
balansae is in this part of the Chaco (Morello and Adámoli 1974) as witnessed by the location of the most important tannin industries.

It must be borne in mind that this forest, like all the forests of the Chaco, has been heavily disturb in the past, and probably now there is not a single stand that is in a steady state or near climax stage. Therefore, after this analysis was completed, one of the transects has been closed with a fence to prevent cattle grazing. In this way some aspects of the dynamics and further evolution of this forest can be studied.

\section{ACKNOWLEDGMENTS}

Financial aid from the CONICET (Council for Scientifical and Technical Research, Argentina) is grateful acknowledged. The authors are indebted to the Santa Fe Ministry of Agriculture for logistic support and the staff of Las Gamas Experimental Center for their invaluable help. J. L. Vesprini and E. Brnich helped with field work and P. S. Torres and J. R. Fernández with computing. We thank three anonymous reviewers for their criticism and useful suggestions that helped us to improve this paper.

\section{RESUMEN}

Amazonia y el Gran Chaco son las unidades fitogeográficas más grandes de Sud América tropical y subtropical. La porción más austral del Chaco oriental es la Cuña Boscosa de Santa $\mathrm{Fe}$, donde la comunidad característica y más difundida es el bosque de Schinopsis balansae (Quebrachal). En uno de estos bosques cerca de Vera, Provincia de Santa Fe, República Argentina, se esTablecieron 32 parcelas contiguas de $10 \times 10 \mathrm{~m}$ a 10 largo de 2 transectas paralelas y en las mismas se hizo un detallado análisis florístico, fisonómico y estructural de la vegetación. Todos los individuos leñosos de más de $0,60 \mathrm{~m}$ de altura fueron identificados y se les midió la altura y el diámetro de sus copas. Con estos datos se construyeron perfiles de vegetación y mapas cartográficos con la ubicación de los individuos. Las especies leñosas fueron clasificadas de acuerdo al tamaño, y textura de sus hojas, presencia de espinas y fenología. Este quebrachal es un bosque abierto de estructura muy compleja y composición florística heterogénea. La mayoría de las especies leñosas de este bosque son deciduas, con hojas pequeñas y frecuentemente con estructuras espinosas. Tiene dos estratos arbóreos altos de $S$. balansae y Acacia praecox. y uno arbóreo bajo de Achatocarpus praecox con individuos juveniles de las especies de los estratos superiores. Existe asimismo un estrato arbustivo de $2 \mathrm{~m}$ de altura. El dosel arbóreo es discontínuo y tiene aberturas que pueden ser bastante grandes, donde el suelo está cubierto por un denso estrato graminoso. Este bosque es similar a otros bosques de $S$. balansae de la Cuña Boscosa de Santa $\mathrm{Fe}$, pero muy diferente de la mayoría de los bosques de otras áreas del Gran Chaco.

\section{REFERENCES}

Adámoli, J. R. Neumann, A.D.R. de Colina \& J. Morello. 1972. El Chaco aluvional salteño (Convenio INTA Prov. de Salta). Rev. Inv. Agropec. INTA, Serie 3 , Clima y Suelo 9: 165-237.

Adámoli, J. E. Sennhauser, J.M. Acero \& A. Rescia. 1990 Stress and disturbance: vegetation dynamics in the dry Chaco region of Argentina. J. Biogeogr. 17: 491-500.

Burgos, J.J. 1970. El clima de la región noreste de la República Argentina. Bol. Soc. Arg. Bot. 11 (suplemento): 37-102.

Cabrera, A.L. 1971. Fitogeografía de la República Argentina. Bol. Soc. Arg. Bot. 14: 1-42.

Cabrera, A.L. \& A. Willink. 1980. Biogeografía de América Latina. Monografías científicas, serie biológica 13. Secretaría General de la O.E.A Washington, D.C. 122 p.

Dansereau, P. 1957. Biogeography. An ecological perspective. Ronald, Nueva York. 394 p.

Davis, T.A.W. \& P.W. Richards. 1933. The vegetation of the Moraballi Creek, British Guiana. an ecological study of a limited area of tropical rainforest. Part 1. J. Ecol. 21: 350-384.

Eskuche, U. 1986. Berich über die 17-Internationale Pflanzengeographische Exkursion durch Nordargentinien. Veröff. Geobot. Inst. ETH, Stiftung Rübel, Zürich 91: 12-117.

Espino, L.M. M.A. Seveso \& M.A. Sabatier. 1983. Mapa de suelos de la Prov. de Santa Fe. Tomo II. MAG Santa Fe-INTA EERA Rafaela, Argentina. 220 p.

Gollan, J. \& D.A. Lachaga. 1939. Aguas de la provincia de Santa Fe. Inst. Experim. de Inv. y Fomento Agríc. Ganadero. Public. Técn. $N^{\circ} 12$. Santa Fe, Argentina.

Gräffe, W. M. Brassiolo, M. Simón, A. Fumagalli \& R. Renolfi. 1991. Explotación eficaz y protección de recursos en la región de la Cuña Boscosa, departamento Vera, provincia de Santa Fe. Area de Sistemas Silvopastoriles de la Facultad de Ciencias Forestales de la Universidad Nacional de Santiago del Estero. Santiago del Estero, Argentina. 83 p.

Lewis, J.P. 1991. Three levels of floristical variation in the forests of Chaco, Argentina. J. Veg. Sci. 2: 125-130. 
Lewis, J.P. \& M.B. Collantes. 1973. El espinal periestépico. Ciencia e Investigación 29: 360-377.

Lewis, J.P. \& E.F. Pire. 1981. Reseña sobre la vegetación del Chaco santafesino. Serie Fitogeográfica 18. INTA, Buenos Aires. 42 p.

Lewis, J.P. E.F. Pire, D.E. Prado, S.L. Stofella, E.A Franceschi \& N.J. Carnevale. 1990. Plant communities and phytogeographical position of a large depression in the Great Chaco, Argentina. Vegetatio 86: 25-38.

Lewis, J.P. E.F. Pire \& J.L. Vesprini. 1994. The mixed dense forest of the Southern Chaco. Contribution to the study of flora and vegetation of the Chaco VIII Candollea 49: 159-168.

Morello, J. \& J. Adámoli. 1974. Las grandes unidades de vegetación y ambiente del Chaco argentino. Segunda parte: vegetación y ambiente de la provincia del Chaco. Serie Fitogeográfica 13. I.N.T.A. Buenos Aires. $130 \mathrm{p}$

Mueller-Dombois, D. \& H. Ellenberg. Aims and methods of vegetation ecology. John Wiley \& Sons, Nueva York. $547 \mathrm{p}$

Mussetti, M. \& D. Alconchel. 1986. Mapa de suelos del Centro Operativo Dr. Tito Livio Coppa. Las Gamas, Depto. Vera, Santa Fe. Dir. Gral. Ext. e Invest. Agrop. Santa Fe, Argentina. 22 p.

Prado, D.E. 1991. A critical evaluation of the floristic links between Chaco and Caatingas vegetation in South America. Ph. D. thesis, University of St. Andrews, St. Andrews, Scotland.

Prado, D.E. 1993a. What is the Gran Chaco vegetation in South America? I. A review. Contribution to the study of the flora and vegetation of the Chaco V. Candollea 48: $145-172$.

Prado, D.E. 1993b. What is the Gran Chaco vegetation in South America? II. A redefinition. Contribution to the study of the flora and vegetation of the Chaco VII. Candollea 48: 615-629.
Ragonese, A.E. \& G. Covas. 1940. La distribución geográfica de los quebrachales en la provincia de Santa Fe. Rev. Arg.. Agron. 8: 176-184.

Ragonese, A.E. \& J.C. Castiglioni. 1970. La vegetación del parque chaqueño. Bol. Soc. Arg. Bot. 11 (suplemento): 133-160.

Ramella L. \& R. Spichiger. 1989. Interpretación preliminar del medio físico y de la vegetación del Chaco boreal. Contribución al estudio de la flora y de la vegetación del Chaco I. Candollea 44: 639-680.

Raunkiaer, C. 1934. The life forms of plants and statistical plant geography. Clarendon, Oxford. $632 \mathrm{p}$.

Richards, P.W. 1952. The tropical rain forest. Cambridge University, Cambridge. $450 \mathrm{p}$.

Sarmiento, G. 1972. Ecological and floristic convergences between seasonal plant formations of tropical and subtropical South America. J. Ecol. 60: 367-410.

Sejzer, D. 1973. Variación de caracteres estructurales y funcionales en comunidades vegetales chaqueñas. Ecología. Asoc. Arg. Ecol. 1: 25-28.

Sennhauser, E. 1991. The concept of stability in connection with the gallery forests of the Chaco region. Vegetatio 94: 1-13.

Spichiger, R. \& L. Ramella. 1989. The forest of the Paraguayan Chaco, p. 259-270. In Holm-Nielsen L.B. et al. (eds.), Tropical forests, botanical dynamics, speciation and diversity. Academic Press, Londres.

Spichiger, R. L. Ramella, R. Palese \& F. Mereles. 1991. Proposición de leyenda para la cartografía de las formaciones vegetales del Chaco paraguayo. Contribución al estudio de la flora y de la vegetación del Chaco III. Candollea 46: 541-564.

Whitmore, T.C. 1990. An introduction to tropical rainforests. Clarendon Press, Oxford. 226 p. 
苟苟

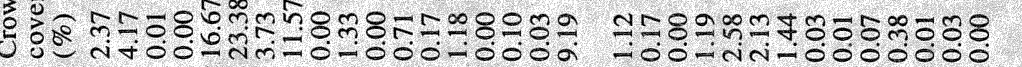

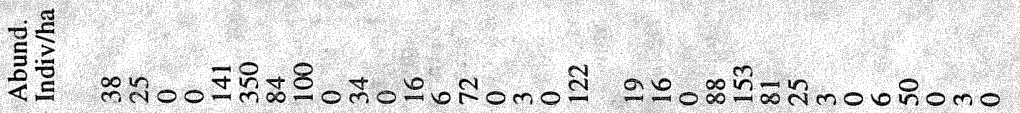

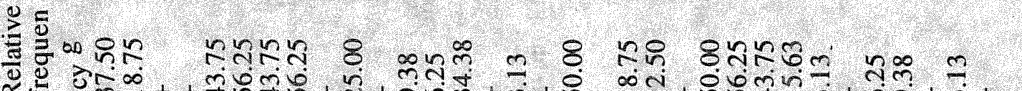

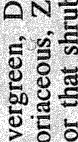
비을 气ี่

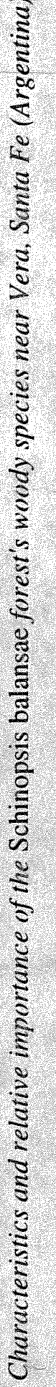

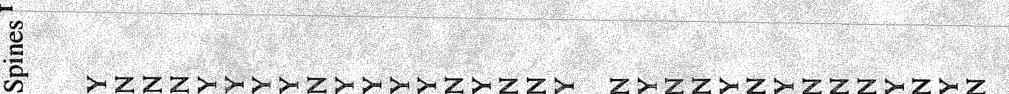

$\overline{8} \times \stackrel{0}{0}$

幽

$\stackrel{0}{0}$

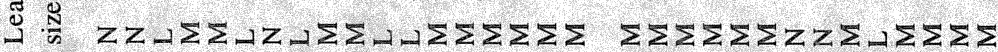

$\because 0$

¿

$\stackrel{\bigcup}{\varrho}$

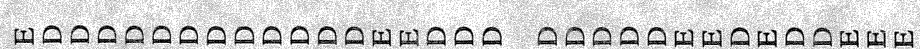

$\frac{0}{\frac{0}{6}}$

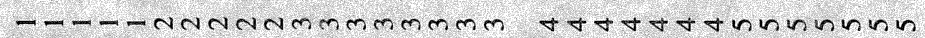

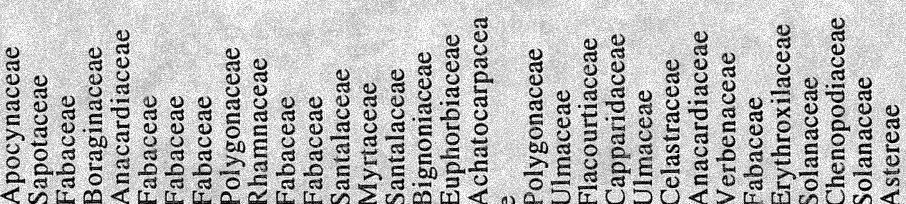

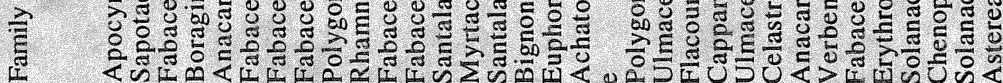

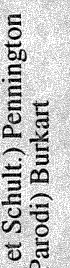

官

हैं हैं

ङั

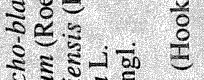

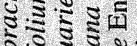

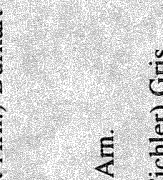

है

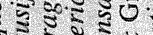

ᄃ

范

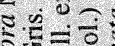

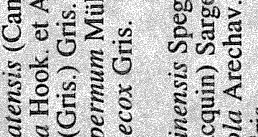

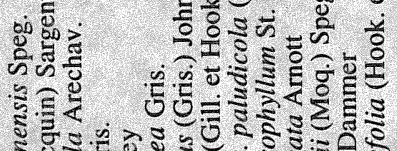

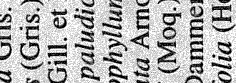

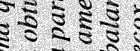

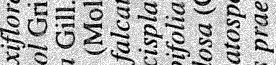

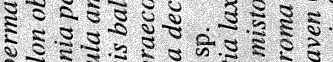

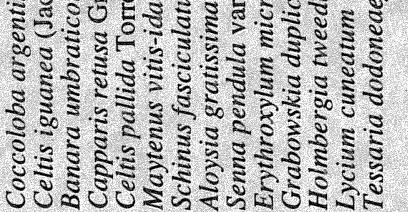

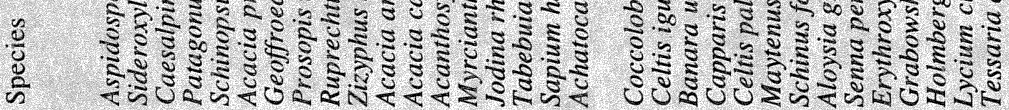

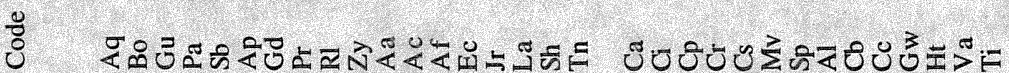


TABLE 2

Leaf characteristics of a Schinopsis balansae forest near Vera (Sta. Fe) in percentage of species, individuals, and cover.

\begin{tabular}{|c|c|c|c|c|c|c|c|c|c|}
\hline \multirow{5}{*}{$\begin{array}{l}\text { Leaf size } \\
\text { Microphyllous } \\
\text { Nanophyllous } \\
\text { Leptophyllous }\end{array}$} & \multirow[b]{2}{*}{ Trees } & \multicolumn{2}{|l|}{ Species } & \multirow[b]{2}{*}{ Trees } & \multicolumn{2}{|c|}{$\begin{array}{l}\text { Individ- } \\
\text { uals }\end{array}$} & \multicolumn{2}{|c|}{ Cover } & \multirow[b]{2}{*}{ Total } \\
\hline & & Shrubs & Total & & Shrubs & Total & Trees & Shrubs & \\
\hline & 55.56 & 78.57 & 65.63 & 38.17 & 92.25 & 54.90 & 38.41 & 83.20 & 43.30 \\
\hline & 16.67 & 14.29 & 15.63 & 14.83 & 6.34 & 12.20 & 13.78 & 16.05 & 14.03 \\
\hline & 27.78 & 7.14 & 18.75 & 47.00 & 1.41 & 32.90 & 47.81 & 0.74 & 42.66 \\
\hline $\begin{array}{l}\text { Leaf texture } \\
\text { Filmy }\end{array}$ & 38.89 & 21.43 & 31.25 & 55.52 & 3.52 & 39.43 & 52.82 & 2.01 & 47.26 \\
\hline Membranous & 50.00 & 64.29 & 56.25 & 40.69 & 78.17 & 52.29 & 44.00 & 74.68 & 47.36 \\
\hline Coriaceous & 11.11 & 0.00 & 6.25 & 3.79 & 0.00 & 2.61 & 3.18 & 0.00 & 2.83 \\
\hline Succulent & 0.00 & 14.29 & 6.25 & 0.00 & 18.31 & 5.66 & 0.00 & 23.30 & 2.55 \\
\hline Leaf type: compound & 33.33 & 7.14 & 21.88 & 55.52 & 0.00 & 38.34 & 52.82 & 0.09 & 47.05 \\
\hline Spines & 61.11 & 35.71 & 50.00 & 89.91 & 55.63 & 79.30 & 92.65 & 50.25 & 88.02 \\
\hline Deciduousness & 83.33 & 57.14 & 71.87 & 88.90 & 75.45 & 84.73 & 95.24 & 60.48 & 91.44 \\
\hline Total (100\%) & 18 & 14 & 32 & 317 & 142 & 459 & 2387.1 & 293.0 & 2680.1 \\
\hline
\end{tabular}




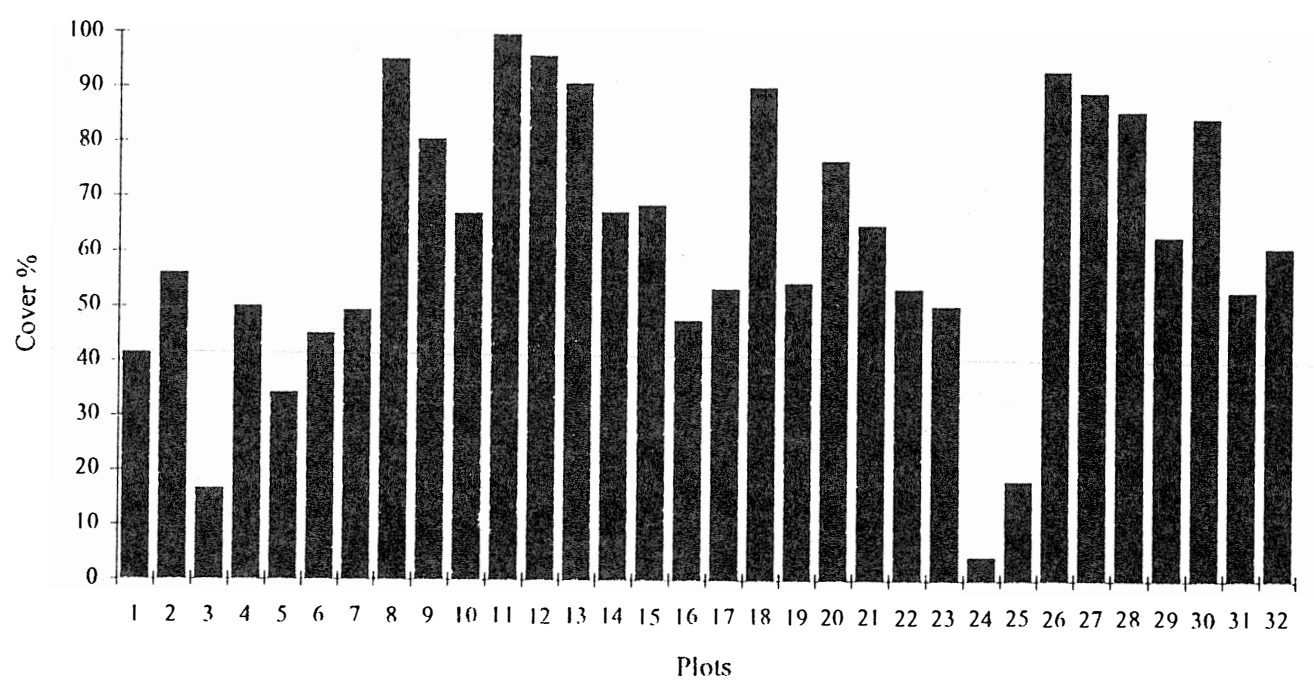

Fig. 1. General cover of tree layers on diff erent plots.

Fig. 2 Cartographic diagrams of woody vegetation of plots 6 to 9 (above) and plots 10 to 12 (below). Al: Aloysia gratissima, Ap: Acacia praecox, Aq: Aspidosperma quebracho-blanco, Bo: Sideroxylon obtusifolium, Ca: Coccoloba argentinensis, Cb: Senna pendula var. paludicola, Ci: Celtis iguanea, Cr: Capparis retusa, Cs: Celtis pallida, Ec: Myrcianthes cisplatensis, Gd: Geoffroea decorticans, Gw: Grabowskia duplicata, Ht: Holmbergia tweedii, Mv Maytenus vitis-idaea, Pr: Prosopis sp. Sb: Schinopsis balansae, Sp: Schinus fasciculatus, Tn: Achatocarpus praecox, Va: Lycium cuneatum, Zy: Zizyphus mistol.

Fig. 3. Profile of the vegetation of the same plots as in Fig. 2. Species symbols also as in Fig. 2. 


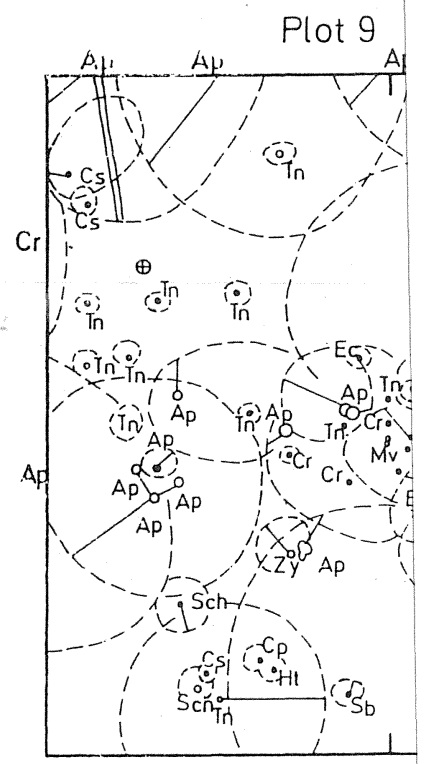

East

$5 m$

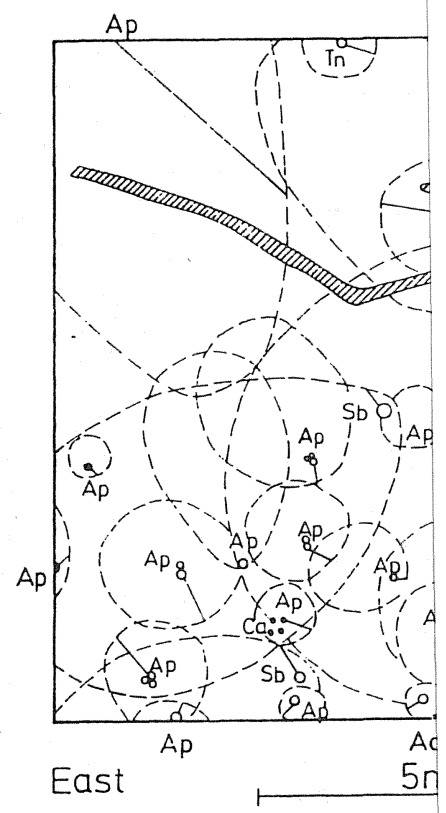



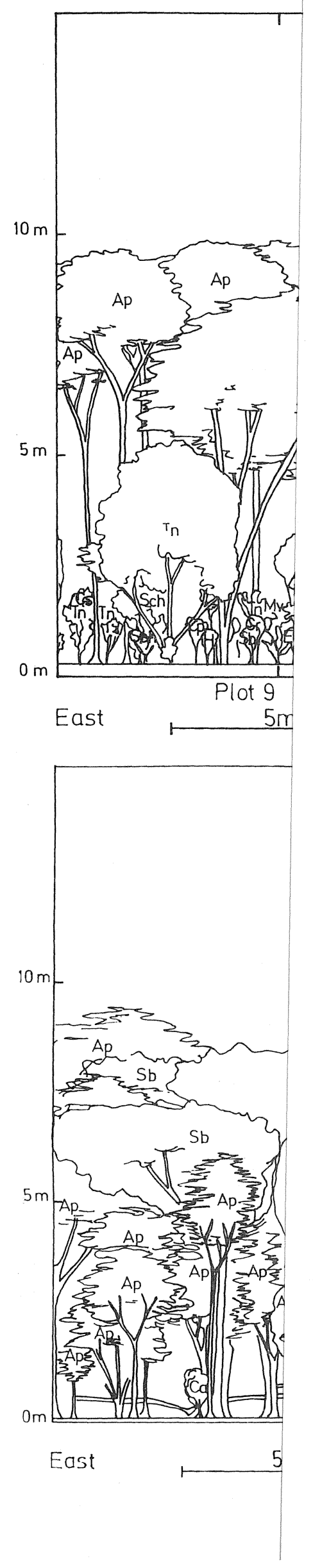